\title{
FAIR INSURANCE COVER FOR EXPORT CREDIT UNDER OECD PRICING FRAMEWORK
}

\section{Mikuláš Pýcha}

\begin{abstract}
This article aims to analyse the issue of a lack of rules on the insurance cover of interest from an OECD perspective during the period 2010-2020. Export credit agencies (ECAs) support export and apply minimum premium rates (MPRs) to the principal amount only, while the insurance agreement covers also the interest amount. This area can be described as a grey zone, because ECAs can decide themselves what cover they provide for a limited price. This paper explains which parts of a lending rate should be covered under credit insurance and provides theoretical and empirical analysis of the maximum extent of interest cover. The extent of such cover is closely related to the return on ECAs' investments. An excessive amount of interest cover creates room for market failures such as moral hazard or adverse selection, which have a negative impact on the domestic economy. The right amount of interest cover, on the other hand, guarantees long-term sustainability and a level playing field among ECAs, as the OECD requires.
\end{abstract}

Keywords: State support, export credit, minimum premium rates, OECD consensus, export credit agency

JEL Classification: G22, G29, H81

\section{Introduction}

We live in times of very low interest rates, which increase the motivation for credit creation, as the price of money is low. Of course, the corresponding credit risk must be acceptable, and that is exactly where export credit agencies (ECAs) are becoming extremely important, because they often cover the credit risk that the commercial market would not accept, thus enabling extra credit to be issued. We have witnessed the huge role played by ECAs in the past year during the SARS-CoV-2 pandemic, as some restrictions on their actions were

\footnotetext{
* This paper was supported by the Czech Science Foundation (Project no. GA 20-00178S) and Prague University of Economics and Business (Projects no. VSE IP100040 and no. IG102029).

a Prague University of Economics and Business, Department of Finance, Prague, Czech Republic Email: xpycm01@vse.cz
} 
removed by the Temporary Framework (2020), which was first published in April 2020 and repeatedly updated later. The European Commission allowed ECAs to support short-term credit for developed countries and also to provide special programmes, such as long-term guarantees covering bank loans. Moreover, the increase in both sovereign and corporate credit risk is analysed by Augustin et al. (2020), who confirm our expectations.

Although ECAs' restrictions have been eased, we have no data to support our expectations of a growing volume in 2020 yet. This analysis remains for future research to continue this study. Not only this development shows us how these institutions grow in importance, which makes it necessary to stress the issues arising from price limitations and the extent of insurance cover - something we currently lack.

When the topic of export credit agencies is raised, one may think about the financing of a domestic product to be exported abroad using credit created by a specific agency that is more or less controlled by the government. This is of course true but, if we take a closer look at this system of state export support, we find there are different financing schemes across the OECD countries. Some of these countries may have only an insurance branch, which provides credit insurance for any commercial bank (or directly for the supplier), while others have, at the same time, a financing branch (like a bank), which ensures that credit is granted even when the banking sector is frozen. Support for export provided in the form of pure insurance could have been seen in the United Kingdom, but now that country provides all kinds of financing schemes in addition to export credit insurance; this is analysed in detail by Saghir (2020). This kind of development could be seen across all OECD members after the 2007-2009 global financial crisis (GFC), when most governments thought they needed their own institution capable of money creation. We have analysed 15 countries, 12 of which have their own institution able to provide pure financing. This trend is presented in Table 1.

However, export credit is vitally connected to export credit insurance, and no export support could exist without it. Credit insurance is, therefore, the core body of export credit support, and the service it provides, in terms of price and the extent of its cover, must be put under greater scrutiny than it has been during the last few years.

The interaction between insurer and credit issuer is the main topic of this paper, because it deals with the problem of pricing risk fairly. The OECD Arrangement allows premium rates to be used no lower than a certain level, known as the minimum premium rate (MPR), yet this rate is applied to the loan principal only and there is no limitation on the amount of insured interest. As this consensus states, the use of official support via export credits should foster a level playing field in order to encourage competition among exporters based on the quality and prices of their goods and services exported rather than on the most favourable financial terms. Our main question here is why we limit premium rates when we do not care about the extent of the insurance cover provided for that price. 
Table 1: Institutional structure of export credit support in selected countries (2020)

\begin{tabular}{|c|c|c|c|}
\hline ECA name & Country & Institutional structure & $\begin{array}{c}\text { Money creation } \\
\text { capability }\end{array}$ \\
\hline EGAP and CEB & Czech Republic & Bank and insurance services & YES \\
\hline Atradius DSB* & Netherlands & Only insurance service & NO \\
\hline KUKE and BGK & Poland & Bank and insurance services & YES \\
\hline OeKB & Austria & Bank and insurance services & YES \\
\hline UKEF & United Kingdom & Bank and insurance services & YES \\
\hline EXIBANKA SR & Slovakia & Bank and insurance services & YES \\
\hline Euler Hermes & Germany & Bank and insurance services & YES \\
\hline Credendo & Belgium & Bank and insurance services & YES \\
\hline SACE and Simest & Italy & Bank and insurance services & YES \\
\hline Finnvera & Finland & Bank and insurance services & YES \\
\hline CESCE & Spain & Only insurance service & NO \\
\hline SERV & Switzerland & Only insurance service & NO \\
\hline EKN and SEK & Sweden & Bank and insurance services & YES \\
\hline EXIAR and EXIMB & Russia & Bank and insurance services & YES \\
\hline US EXIMBANK & USA & Bank and insurance services & YES \\
\hline
\end{tabular}

Note: Abbreviations used in this table are presented at the end of this paper.

*Preparation for opening a financing branch announced publicly.

Source: Own analysis.

There has to be a general agreement among all participating countries to limit pricing for this kind of insurance by connecting it clearly to the relevant insurance cover. Basically, we look for a formula that would help us find the right amount of insurance cover that actually includes the whole costs of financing, including operating costs. However, it is vitally important that such insurance cover should never guarantee a profit for the insured party (a bank) in the case of a debtor's default. In today's world of export credit, the system works best for insured banks, because they do not really have to worry about the risk of a debtor's default if the interest rate margin is high enough. The bank achieves a profit either way, because the insured loan will always be repaid, either by the debtor or the insurer, which means the ECA. Once we start looking at this issue from the whole market perspective, we end up finding clear examples of those market failures known 
as moral risk and adverse selection. It is in the nature of a bank to make a profit, and we cannot blame banks for doing what they are meant to do, so instead we shall stress the duty of the rule-makers to eliminate such market failures.

Only the right pricing scheme can manage to reduce the advantage enjoyed by insured banks in the export credit system. Once the MPRs, which represent the lower limit for premium rates, are joined by a corresponding maximum limit on the amount of insured interest, then banks may be more likely to start selecting healthier commercial clients and may also care more about their risk of default. When we find such a formula for insurance cover limitation, then the market failures mentioned above will vanish.

This paper is structured into five sections. The first section introduces the reader to the problems of export credit support. Section 2 describes the current state of research and knowledge in this area and explains why this research is enriching. The third section describes the methodology used, while the fourth presents the empirical results, and the fifth section presents the conclusion.

\section{Literature Review}

When deciding what direction this research in the field of ECAs should take, I studied many papers that had been published historically. I had always wondered why there is a lack of papers dealing with pricing issues among ECAs, even though this area is quite wide and grows in importance in times of low (often below zero) interest rates. To understand how pricing might have evolved into its current state, one needs to know the history of ECAs and their rules that are agreed at the OECD level. This historical development is nicely analysed and described by De Ricolfis (2011). However, that paper does not touch on the potential problem with pricing, and the author only takes a closer look at the roles of the OECD and the Berne Union in connection with the establishment of many of today's well-known ECAs in developed countries. It is widely known that export support is provided mostly in developed, high-income countries. There are many explanations for this trend, although there has always been a question whether, and in which form, a country should have an ECA to provide such support. This question is debated by Chauffour et al. (2010), who agree that running an ECA makes more sense in developed countries than in developing countries. The valuable output of that paper is a set of requirements for a developing country deciding whether it is reasonable to establish its own ECA.

These requirements basically evaluate whether the level of economic development is high enough for such an institution to be operated. It is indeed clear that we need to evaluate the financial strength and credibility of a country to know whether a new ECA can be successful. If a country's financial system lacks credibility, then the attainable financing 
costs will be quite high and hardly acceptable for a foreign buyer at such a level of credit. This idea is clear and simple; moreover, it explains why it is harder for developing countries to finance export support in the same way that developed countries do.

This theory can also be seen in the real world, and the biggest ECAs are indeed located in the most developed countries with low interest rates. This leads to the fact that most papers that are written on the topic of support for national export target national issues and deal with certain patterns, which are specific to only one country. In North American literature, we may find a paper written by Baas (2010), analysing the situation in Canada, while Ilias et al. (2012) describe the specifications of a special programme to encourage export in the United States during Obama's presidency. When we move to the other side of the Atlantic, we find that Europe is actually full of ECAs, as every country here runs such an institution and they all belong under the OECD Arrangement and therefore follow the Red Book (2020) of rules to avoid market distortion. However, it is necessary to mention that EU members are represented as one participant at the OECD level.

As in North America, many authors in Europe have analysed the microeconomic issues in each country. An empirical analysis made by Felbermayer and Erdal (2013) explains how vulnerable exporters are to market frictions and how important a role is played by Euler Hermes and their products when this happens. The process of internationalization in France is described by Belhoste et al. (2019), who compare traditional French small and medium enterprises with venture companies entering Asia and the role of support services such as Coface or BPI France. Moving east, another interesting study was made in the Czech Republic by Janda et al. (2013), who analyse a large sample of countries where Czech companies export and explain which variables are most favourable for exports. It is not surprising that low political risk is one of the most important values here, which shows the importance of the existence of ECAs when an exporter has the chance to make a deal with a company in a country with higher political risk. Another micro-analysis focused on small and medium enterprises can be found in Slovakia. According to Ključnikov and Popesko (2017), a very large proportion of these companies lack faith in national export support and do not even attempt to use such help.

As there are many papers analysing individual countries from the perspective of their export habits and the structure of their export credit support, it is almost impossible to find a study discussing the interaction between a bank and an ECA. This shadowy area has obviously not been researched much yet. However, it may be very important to understand how the OECD rules control this relationship in order to ensure a "level playing field" for all. The question here is what price these institutions charge. A bank creates a loan for a certain price; this price is represented by the interest rate. If a bank is an ECA at the same time, there is a lower limit set by the OECD called the commercial 
interest reference rate (CIRR) that is meant to guarantee no market distortion. A deeper analysis of the CIRR structure was performed by Sharov et al. (2018). This study also touches on minimum premium rates (MPR) and suggests that there is a certain minimum price of credit risk that cannot be lowered either in the CIRR or MPR. In the real world, loan creation is mostly performed by commercial banks that insure themselves with ECAs against the risk of a debtor's default. Interest rates on such loans never go as low as CIRR rates do, so it appears that all is well and good and the market may not be under any threat of distortion. The main aim of this paper is to explain why it could be under threat, and why the OECD needs to set some limits on the interest insurance cover.

The high possibility of a distortion of the market under the current system of official export credit support is also seen by Dawar (2020), who states that the terms of the support a foreign buyer can obtain from an ECA have become an increasingly important factor in the choice between different exporters. This tells us that exporters around the world compete not only on the quality and price of their products, but, more importantly, it emphasizes that the final price for the foreign buyer (importer) depends heavily on the financing terms that a particular ECA can offer. Another highly topical article published by Kim (2020) expresses concerns that credit guarantees or insurance may easily distort healthy competition in world trade. This paper links the export credit programmes in specific countries with the WTO Agreement on Subsidies and Countervailing Measures (SCM Agreement).

The importance of the sustainability of export support has been increasing in the past few years, as we can see in the most recent articles appearing globally, although they do not directly address the relationship between the amount of insurance cover and its price. A possible threat to state budgets arising from excessive export support, which may create systematic losses over a long period of time, is described by Pycha (2020). It seems that the OECD Arrangement does not make any connection between the MPRs and the total amount of insured value, because a significant part of the insured value consists of insured interest, while the premium rate is applied only to the insured principal amount. When a debtor fails to repay a loan, an ECA takes the debtor's place and starts paying not only the principal payments, but also the corresponding interest payments.

After a comprehensive examination of the available studies in the area of pricing and the corresponding insurance cover under the OECD Arrangement, we believe that there is an obvious lack of research in this area. Our goal is to draw attention to this missing area and provide possible ways to solve the debated issue. It makes perfect sense to continue in our current research and analyse what is the right amount of maximum insured interest that should be considered by OECD members to avoid market distortions and negative impacts on state budgets. Moreover, it is vital to ensure that insured subjects receive 
comparable insurance cover for the same MPR, because it is unacceptable that a German bank should receive higher insurance cover than a French bank receives from its ECA.

\section{Methodology}

To obtain the fair amount of insurance cover when the MPR is paid, we need first to understand how, in theory, the price of a loan is structured by a bank. We consider a bank to be either an ECA or any commercial bank, but an insurance provider can only be an ECA, due to the fact that that kind of insurance is never profitable and requires a lot of own funds, which simply generate no return. One law that should never be broken is set by the OECD Arrangement and requires ECAs to be long-term sustainable with no systemic dependence on state budgets. In brief, this means that the written premium must equal the total amount of claims payments plus operational costs. This requirement clearly avoids market distortion. MPRs have to satisfy this, and therefore we will try to show what the maximum amount of interest cover is when the premium rate is not applied to the full insured value, as such a principle is much more common in the insurance industry. We will start with a basic equation that describes the price of a loan and its structure. Then we will analyse each part of it and establish what should be covered by ECA insurance according to the OECD Arrangement.

\section{Equation 1: Price of the loan charged by a bank}

$$
P_{\text {Financing }}=P_{\text {Money }}+R_{\text {Credit }}+R_{\text {Market }}+C_{\text {Operational }}+M_{\text {Profit }}
$$

We work with the theory that any bank providing loans has to be able to price them correctly to cover all related costs and also make some profit. This equation basically sums up the major parts that influence the final price of financing $\left(P_{\text {Financing }}\right)$ represented by the interest rate that is applied to the unpaid part of the principal. The modelling of the price of a loan with relation to government debt is analysed by Navarro-Galera et al. (2015), which is a valuable study for our research, because we believe that using ECAs to provide credit insurance without interest cover limitations causes systematic losses to the government. The equation above has five parts that influence the final price of financing. The question to be answered is how much of it can be covered by an ECA via a credit insurance agreement.

Firstly, price of money $\left(P_{\text {Money }}\right)$ stands for the costs of financing, which in our case are based on a certain reference rate for financing. In other words, it is the interbank offered rate for a chosen currency. These rates are considered to be practically risk-free as they refer only to the price of money. In our study, we will use CIRR rates instead of those rates, because they too are considered, and structured, to be risk-free. The classic 
CIRR rates published monthly by the OECD are increased by $100 \mathrm{bps}$, but we would rather work with rates that do not include such a surcharge. The rates without a surcharge of 100 bps are called CIRR base rates. The reason for choosing mainly EUR and USD can be explained by the fact that most of the export credit issued by ECAs is denominated in those currencies. In the case of a default, this part of $P_{\text {Financing }}$ is definitely covered by an ECA insurance agreement.

Secondly, the largest part of a loan's price is determined by the credit risk $\left(R_{\text {Credit }}\right)$, which is closely connected with the recipient of the loan and the probability of default. Credit risk is an area of common interest for both the insurer and the insured, because banks transfer this risk to ECAs to be covered by them and they keep only a small portion through self-retention. For such a service, banks agree to pay a premium. So, as we can see, credit risk breaks down into two parts, as shown in Equation 2.

\section{Equation 2: Credit risk breakdown between an ECA and its insured party}

$$
R_{\text {CREDIT }}=R_{\text {TRANSFERRED TO ECA }}+R_{\text {SELF-RETAINED }}
$$

The part describing the risk transferred to the ECA will no longer be part of $P_{\text {Financing, }}$, as the corresponding risk has been removed. The part self-retained by the bank could influence $P_{\text {Financing, }}$, as it corresponds with a debtor's credit risk. The purpose of self retention is to minimize the moral hazard arising from the insurance contract, and such risk must be borne by the insured alone and shall never be transferred in any way to the insurer. Sometimes it is not clear whether banks actually remove this part from the total price, even though, in our research, we deal with a considerable amount of insurance coverage. To sum up, the $R_{\text {Credit }}$ as a whole should not be covered by an ECA and is, therefore, never indemnified.

Thirdly, market risk consists mostly of changes in interest rate risk, which can be easily measured by interest rate swaps (IRS). Foreign exchange risk is also part of market risk, but most ECAs in the developed world insure credit issued in their own currency, or they keep and invest the collected premium in the original currency until indemnification. Therefore, we assume that foreign exchange risk does not have to be considered here. Other market risks, such as liquidity risk, spread risk or commodity risk, are not considered, as they have no bearing on the credit insurance provided by ECAs. It appears that the price of fixing the interest rate is also a subject to be covered by ECAs.

Fourthly, operational costs incurred by insured banks to provide credit for exporters must be understood as a necessary price for credit to be issued. In the event of a loss, banks must know that they will receive indemnification covering not only the amount of lost credit, but also corresponding to the operational costs. If this requirement is not met, banks would face losses due to ineffective insurance cover in the case of a default, which is 
unacceptable. The part of the total costs represented by operational costs is an appropriate subject to be covered by an ECA.

The last part deals with the planned profit of a bank, and no ECA should support the profitability of the banking sector, because that support is meant for exporters and definitely not for banks. Banks should break even if their business case fails, and may achieve some profit if it succeeds. This means that the profit margin must never be covered by an ECA.

Analysing and breaking down the structure of a bank's interest rate into smaller parts shows us which parts might or might not be part of insured interest. However, it does not tell us anything about the level of maximum interest coverage. To be more specific, we need to know how much insurance cover above the risk-free rate can be offered by ECAs in order to still maintain long-term sustainability when applying the MPR to the principal only. This basic long-term equilibrium can be guaranteed only if the total written premium collected up front covers future claims payments and relevant operational costs. A standard practice among ECAs is that the premium is calculated based on MPRs and then collected up front, and we assume that deviation from that practice happens only exceptionally.

\section{Equation 3: Free portion of the written premium collected by ECAs to be invested}

$$
\text { PREMIUM }_{\text {TO BE INVESTED }}=\text { WRITTEN PREMIUM } M_{\text {TOTAL }}-C_{\text {Operational }}
$$

This equation has already been mentioned in the text above, but there we expressed it only for the part of a collected premium that is free to be invested. As this amount equals the future claims payments, ECAs can earn some interest before using it for such payments, which means they can use it in the future for claims payments that are now higher than the principal only and will still be even in the long-term. The current structure of the MPR does not publicly state what part of it is allocated to operational expenses. However, ECAs apply the TCMB model to price risk in high-income countries, and the guidance on premium rules for officially supported export credits in market benchmark countries states that $20 \%$ of the MPR is used to cover operational costs, while the remaining $80 \%$ covers the credit risk, which means future claims payments. It is clear that a highly cost-effective ECA may provide more cover and still be as long-term sustainable as a cost-ineffective ECA with a lower insurance cover. For our analysis, we accept the simplification that ECAs in general cannot influence the amount of their insurance cover by their expense ratios, so we can adjust and enrich Equation 3 as follows:

\section{Equation 4: Long term sustainability of an ECA}

$$
\sum \text { PREMIUM }_{\text {TO BE INVESTED }} \mathrm{x}(1+\mathrm{R})^{\mathrm{n}} \geq \sum C L A I M P A Y M E N T_{n}
$$


The major finding in our study is that long-term sustainability can be maintained only if Equation 4 holds. The sum of all claims payments must be equal to or lower than the collected premium plus earned interest for the time $n$, which represents the period between receiving the premium and paying the claim to the insured party. The maximum amount of interest insured by ECAs then directly hinges on the return of their investments. In other words, no ECA should insure interest payments above the level of return it can reach on the market with its investments.

To calculate the estimate of the investment return for ECAs, we choose two possible approaches. Firstly, we adjust the capital asset pricing model (CAPM) designed for that purpose to calculate the expected return of an ECA's portfolio. Secondly, we analyse numerous annual reports of insurance companies and ECAs and their realized returns on investments during the last 10 years, where we look at the average realized returns compared to the risk-free rates during the same periods.

According to Fama et al. (2004) the CAPM model does not provide precise results. However, for our study we need an estimate of the possible returns that can be achieved by ECAs. Even Fama, in his paper, confirms the connection between risk and return and their inverse relationship, which was explored more than half a century ago by Markowitz (1959) in his study dealing with optimal portfolio choice. From our perspective, ECAs are insurance companies that invest their free money as any other institutional investors, and, as it is in their nature to keep the risk very low, their investments bring a relatively low return. ECAs are characterized by the long tenors of their insurance, which provides them with large amounts of money for a relatively long period of time, so they do not need high liquidity, and the return on their investments may not be so low. The final adjusted model used to estimate the expected return of an ECA's portfolio has the following structure.

\section{Equation 5: Adjusted CAPM model to estimate the return of an ECA's portfolio}

$$
E(R)_{\text {PORTFOLIO }}=\operatorname{CIRR}_{\text {BASE }}+\beta\left(E(R)_{\text {MARKET }}-C_{\text {BIRA }}\right)
$$

Instead of using the reference risk-free rate, we use the above-mentioned CIRR base rate, which is updated and released on a monthly basis by the OECD ${ }^{1}$. CIRRs are calculated as an average of the relevant daily spot rates for triple-A EURO government bonds and therefore they fully represent a risk-free rate for each currency. These rates are available for multiple currencies and also for a number of repayment periods, which makes them perfect for use here.

1 Available at: https://www.oecd.org/trade/topics/export-credits/documents/cirrs.pdf 
To obtain the estimate, it is necessary to resolve which beta to use for such a portfolio and then find the right market benchmark for the expected return in order to ascertain the market risk premium $\left(E(R)_{\text {MARKET }}-C_{\text {IIR }}\right.$ BASE, which is sensitive to the beta value. This beta value represents the systematic risk, while the unsystematic risk can be fully diversified, and we assume that all institutional investors are able to achieve that. This approach is also supported by Gründl et al. (2017), who say that only systematic risk determines the final return of an investment. As we look for a beta that is suitable for an ECA's portfolio, we need an unlevered beta value, as ECAs never use loans or debt to increase their return on investment. Moreover, we know that the portfolio of an ECA, as an institutional investor, must be very conservative with lower systematic risk, which leads us to look for a beta value lower than the average would be. One source of beta values is available at Damodaran Online, where one can find betas for all possible sectors. We choose to use the 15 lowest values of average unlevered beta to obtain the final value, which, from our perspective, is the best estimate of an ECA's portfolio beta.

\section{Empirical Analysis}

\subsection{Data description}

We work with a time series of data from 2010 to 2020, which gives us information about the development over the last ten years for most of the inputs used. The data for individual countries are collected only until the end of 2019 as data for 2020 are not publicly available yet.

For the market benchmarks, different major indices from the European Union and the United States are used for this analysis. From our perspective, these indices represent the best options for a market benchmark for investment returns in both euros and USD. The final results are then annualized to enable comparability and they are shown in the following table.

Table 2: Market benchmarks based on different indices (2010-2020)

\begin{tabular}{l|c|c|c}
\hline \multicolumn{1}{c|}{ Index name } & $\begin{array}{c}\text { Underlying } \\
\text { currency }\end{array}$ & $\begin{array}{c}\text { 5-year realized } \\
\text { return (\%) }\end{array}$ & $\begin{array}{c}\text { 10-year realized } \\
\text { return (\%) }\end{array}$ \\
\hline EURONEXT 100 & EUR & 3.95 & 4.54 \\
\hline EURO STOXX 50 & EUR & 1.90 & 2.54 \\
\hline DJI Industrial Average & USD & 11.78 & 10.14 \\
\hline S\&P Corporate Bond & EUR & 2.59 & 3.43 \\
\hline S\&P Sovereign Bond & EUR & 3.01 & 4.15 \\
\hline
\end{tabular}

Source: Own analysis 
To estimate market benchmarks for EUR, we use 4 different indices, while for USD we accept just one as other indices are hard to use due their volatility or comparability. However, for USD we choose the world-known Dow Jones Index, which is globally respected as an example of market benchmarks, which lead us to conclude that it will be sufficient.

When analysing the realized returns of insurance companies, we use the reported amount of investments that generates interest income in any form according to annual reports. We have analysed realized returns for 11 commercial or public institutions registered in 9 countries. We were able to obtain these data for the Czech Republic, Denmark, Estonia, France, Italy, Poland, Sweden, Switzerland and the USA. The realized return is then calculated on an annual basis from the average amount of investments, which is obtained from static values from the end of the previous two years. In the end, the realized return is adjusted by the risk-free rate for the period when the return was realized, in order to obtain comparable values for the CAPM estimates, which give us a net return above the risk-free rate.

\subsection{Results}

Our contribution is twofold. Firstly, we provide a theoretical analysis of the maximum extent of interest cover above the risk-free rate. Secondly, our empirical results imply that ECAs can easily provide insurance cover of interest above the CIRR rates, and the MPR can still be applied to the principal value only. We started by presenting our results with CAPM estimates of the expected returns that insurance companies could have. As the beta value stands for the undiversifiable risk, we assume it must be low, so we took the dataset from Damodaran, and used the average value of beta of the 15 lowest titles sorted by industry type. Following this, we obtained a beta value of 0.46 , which we consider reasonable for such non-aggressive institutions as ECAs on the investment market.

The indices used as expected market returns represent values that could be considered to be market benchmarks. We split the results into two groups that differ in their duration, as we look at historical performances in the last 5 and 10 years. The results are appealing, because the American market benchmark presents significantly higher returns than the one in Europe. According to Table 2, it seems that the American benchmark denominated in USD shows returns on investment up to 3 or 4 times higher than the European average does.

Our results very probably relate with different usage of capital markets between Europe and America and its natural way of financing, which has a historical pattern and the high expected return for USA may easily include higher risks. As these results 
indicate differences, we propose to analyse returns above the risk-free rate separately based on the currency. The following table summarizes these benchmark values and also compares them with the risk-free rates that are represented by CIRR base rates.

Table 3: CIRR base rates as risk-free interest rates and market benchmarks (2010-2020)

\begin{tabular}{l|c|c}
\hline Currency name & $\begin{array}{c}\text { Market benchmark } \\
\mathbf{5} \text { yrs (\%) }\end{array}$ & $\begin{array}{c}\text { Market benchmark } \\
\mathbf{1 0} \text { yrs (\%) }\end{array}$ \\
\hline Euro (EUR) & 2.86 & 3.67 \\
\hline American dollar (USD) & 11.78 & 10.14 \\
\hline CIRR base (EUR) & -0.76 & -0.69 \\
\hline CIRR base (USD) & 0.39 & 0.63 \\
\hline
\end{tabular}

Source: Own analysis

It is clear that it is not only the returns on investments that differ between dollar and euro investments; the risk-free rates are not so close to each other either. The CIRR base rates are chosen, as they are the most recent ones available. These data can now be used to estimate the expected return of insurance portfolio adjusted by a CAPM model. However, we may have a different duration of an investment, and the investment may also be in different currencies. We therefore present multiple results for the estimate of the expected return on investment by inputting variables into Equation 5.

Table 4: Expected return on an insurance portfolio according to the adjusted CAPM (2010-2020)

\begin{tabular}{l|c|c}
\hline Scenario & \multicolumn{1}{|c|}{ CAPM calculation } & $\begin{array}{c}\text { Estimation of return over } \\
\text { the risk-free rate (\%) }\end{array}$ \\
\hline 5yrs duration; EUR & $E(R)_{P}=-0.76 \%+0.46 \times(2.86 \%+0.76 \%)$ & 2.67 \\
\hline 10yrs duration; EUR & $E(R)_{P}=-0.69 \%+0.46 \times(3.67 \%+0.69 \%)$ & 5.25 \\
\hline 5yrs duration; USD & $E(R)_{P}=0.39 \%+0.46 \times(11.78 \%-0.39 \%)$ & 4.38 \\
\hline 10yrs duration; USD & $E(R)_{P}=0.63 \%+0.46 \times(10.14 \%-0.63 \%)$ & 2.01 \\
\hline
\end{tabular}

Source: Own analysis 
The adjusted CAPM model shows that insurance companies could have a return on their investments ranging from $167 \mathrm{bps}$ to $201 \mathrm{bps}$ above the risk-free rate in the euro currency, while those figures are more than doubled for the dollar currency. Once we added the risk-free rate, the results are not so different for the chosen currencies, but our estimate of return above the risk-free rate is still significantly higher in the USA, which needs a reasonable explanation. We believe that our results could be influenced by the chosen period as the GFC depressed the USA the most and the following growth after the crisis surpasses its long-term average. The US market may also grow too much due to unfounded expectations of keeping the growth the same in future, which may create financial bubbles. When these bubbles burst, the US market benchmark could decrease somewhat. On the other hand, the euro market struggles with debt issues that push interest rates down heavily, even below zero. This situation very probably lowers the attainable return on any investment denominated in EUR.

Results of adjusted CAPM indicate that ECAs could provide insurance cover of interest that would be based on the CIRR rate plus this estimate of return above the risk-free rate for each corresponding currency. It can now be confirmed that ECAs can provide extra insurance cover of interest even if they apply MPRs only to the principal value. However, the insured amount of interest must comply with the underlying currency and must also comply with the ECA's return on investments which guarantee long-term sustainability.

As the adjusted CAPM model provides only rough estimates of return, the results should be validated by a detailed analysis of the realized returns on investment from different insurance companies. We tried to analyse mostly ECAs' annual reports if those were available. However, for some countries we added commercial insurance companies, as we believe that they all invest under the same restraints and therefore have the same opportunities.

The empirical results on insurance portfolio returns on investments indicate that the adjusted CAPM model used in this paper is not very far from realistically achievable values. To obtain the average, we chose CIRR rates with repayment terms of over five and up to eight and half years as these are constructed out of five-year government bond yields (Red Book, 2020). Insurance companies in Europe, mostly ECAs, achieved a return on their investments of almost $1.6 \%$ per annum above the CIRR base rate in the last 5 years, which falls a little to the value of $1.07 \%$ per annum if we look at the last 10 years. In the USA, insurance companies realized returns above the CIRR base rates that are slightly higher than those of European countries. One compelling finding is that the adjusted CAPM model estimated much higher returns in the USA, while the analysis of realized returns in the USA ranges in absolute values from $2.03 \%$ to $2.44 \%$ per annum above the risk-free rate. 
Table 5: Realized returns on investments by insurance companies in selected countries above the risk-free rate (CIRR base rates represent risk free rates)

\begin{tabular}{l|c|c|c|c}
\hline Country & $\begin{array}{c}\text { Average CIRR } \\
\text { base rate } \\
\text { in 2015-2019 (\%) }\end{array}$ & $\begin{array}{c}\text { Average CIRR } \\
\text { base rate } \\
\text { in 2010-2019 (\%) }\end{array}$ & $\begin{array}{c}\text { Average return } \\
\text { above CIRR rate } \\
\text { in 2015-2019 (\%) }\end{array}$ & $\begin{array}{c}\text { Average return } \\
\text { above CIRR rate } \\
\text { in 2010-2019 (\%) }\end{array}$ \\
\hline Czech Republic & 0.63 & 1.27 & 1.03 & 0.63 \\
\hline France & -0.26 & 0.57 & 2.60 & 1.79 \\
\hline Sweden & -0.07 & 0.84 & 1.67 & 1.11 \\
\hline Italy & -0.26 & 0.57 & 3.02 & 2.23 \\
\hline Poland & 2.38 & 3.42 & 0.40 & 0.40 \\
\hline Denmark & -0.21 & 0.49 & 0.91 & 0.23 \\
\hline Estonia & -0.26 & 0.57 & 2.49 & 1.65 \\
\hline Switzerland & -0.62 & -0.05 & 0.64 & 0.54 \\
\hline All European & 0.16 & 0.96 & $\mathbf{1 . 5 9}$ & $\mathbf{1 . 0 7}$ \\
\hline USA & 1.90 & 1.66 & $\mathbf{2 . 0 3}$ & $\mathbf{2 . 4 4}$ \\
\hline
\end{tabular}

Source: Own analysis

We believe that our adjusted CAPM model estimates higher returns for USA than the truly realizable return, because insurance companies are in general very conservative investors and they would avoid risky assets. According to our belief, the Dow Jones index may include higher credit risk and therefore such risk keeps institutional investors away and then they cannot reach the expected market benchmark return weighted by the chosen beta factor.

\subsection{Summary of results}

The analysis of realized returns confirms that it is possible for ECAs to cover a certain amount of interest above the risk-free rate. The output is the same as indicated by the adjusted CAPM model, but the values are a bit lower in the real world, especially in the USA. It must be said that the CAPM model is very sensitive to the chosen market benchmark return, which can cloud the true result. Nevertheless, it is very important to note that ECAs can, according to this study, provide insurance cover of interest corresponding to the risk-free rate plus roughly $160 \mathrm{bps}$ for loans denominated in euro, while for loans in USD, even higher interest cover - about 240 bps above the risk-free rate - is feasible. 
We assume it would be worth comparing our findings with similar relevant studies in this field; however, there are no articles to provide such comparison. As mentioned above in the literature review, this paper is unique and its main aim is to enrich the economic theory describing acceptable volumes of insured interest by ECAs under OECD pricing in order to fulfil general rules.

Based on the outcomes of this research, we would strongly recommend establishing a maximum level for insured interest at the OECD level. Of course, a consensus among all the participants would have to be found. Nevertheless, the absolute maximum of insured interest should never exceed the amount corresponding to the relevant annual CIRR base rate plus 250 bps. After such a decision is made, it must become a part of the OECD Arrangement. We simply cannot demand the long-term sustainability of ECAs while letting them insure an unlimited or arbitrary amount of interest above the principal, to which we apply the MPR and calculate the premium.

\subsection{Further research opportunities}

This research into a fair price for export related to a fair amount of insurance cover can, of course, be developed further. In the euro zone in particular, we witness the same CIRR base rates for all countries using euros, while government bond yields differ across them significantly. The yield of a German AAA bond is far lower than that of the same AAA bond issued by Italy or Greece, even though it is the same currency. This leads to some euro-using countries being less credible than those countries (mainly Germany) used for the CIRR calculation providing financing that is unfair for the area. This means that the peripheral countries in the euro zone use the same CIRR rates as Germany does, although it has been clear for a long time that such a rate is beyond the reach of those peripheral countries as they are strongly indebted. Deeper research into the topic suggests that using such CIRR rates makes ECAs in the southern part of the euro zone unsustainable in the long term. This kind of analysis also shows that governments may actually be content with the losses made by ECAs, because they have a positive impact on public finances. It might be very appealing to analyse deeper the impact of export support on public budgets and try to measure the impact on the domestic economy. The positive impact of export support could help to understand why long-term sustainability is not a problem for many governments.

\section{Conclusion}

In this paper, we question the current system of export credit insurance that is provided by ECAs around the world according to the agreed OECD rules, which are meant to guarantee 
a so-called level playing field for exporters. In brief, this means that exporters are meant to compete on the quality and price of exported goods and services, while financing terms should never play a role. However, the real situation is different, because all ECAs apply the MPR to the principal value only, but insure the interest amount as well. This practice is very unusual in the world of insurance, where the premium rates are always applied to the insured value. In our previous paper, we showed that the amount of insured interest plays a critical role regarding expected loss, which led us to write this follow-up paper to show how much interest ECAs can actually afford to insure above the risk-free rate.

The analysis shows how the lending rate is structured by a bank, and it is a crucial issue, because it contains parts that must never be insured by ECAs. If an insurance company insures too much interest for the value of the MPR that is applied to the principal, it may easily trigger market failure. Moral risk is created when insured banks cannot lose anything when a business case collapses, and it must, therefore, be guaranteed that, in such a case, banks end up at best even. Banks can be allowed to make a profit only on successful business cases. Secondly, if the approach described above works, banks will reduce adverse selection, and fewer senseless and loss-making business cases will appear. A detailed analysis of the final price of financing demonstrates to what extent it may be insured to create an economic environment that prevents such market failures from occurring. However, this part of the analysis does not directly answer the major question of what the fair price could be in absolute values.

To answer this, we had to use the OECD requirement that ECAs must be sustainable in the long term, and, therefore, they may pay out only as much as they have already collected. Insurance companies, among which there are surely also ECAs, are considered to be strong institutional investors, because they invest large amounts of free finances. These institutions are very sensitive to risk, and they invest very conservatively. This analysis is structured to show that ECAs can provide interest cover only to the extent of their achievable return on investments.

Results show that ECAs are able to make extra profit above the risk-free rate. In our study, we consider CIRR base rates to be risk-free rates as they are calculated from the yields of relevant government bonds (they use AAA government bonds for EUR). In absolute values, we found that ECAs are capable of making returns above CIRR base rates ranging from $100 \mathrm{bps}$ to $250 \mathrm{bps}$. This amount can then be used for indemnification, and insurance cover can, therefore, include the interest cover of that amount. 


\section{Appendix}

\section{List of abbreviations}

BGK

BPI France

bps

CAPM

CEB

CESCE

CIRR rate

CIRR base rate

ECA / ECAs

EGAP

EKN

EU

EXIAR

EXIMB

EXIBANKA SR

GFC

KUKE

MPR

OECD

OeKB

SACE

SEK

SERV

Simest

TCMB model

UKEF

P_Financing

P_Money

R_Credit

R_Market

C_Operational

M_Profit
Bank Gospodarstwa Krajowego (Poland)

Banque Publique d'Investissement accompagne (France)

Basis points

Capital Asset Pricing Model

Czech Export Bank

Conoce los seguros de caución y de crédito a la exportación (Spain)

Commercial Interest Reference Rates

CIRR rate lowered by 100 bps

Export Credit Agency / Export Credit Agencies

Export Guarantee and Assurance Corporation (Czech Republic)

Exportkreditnämnden (Sweden)

European Union

Russian Agency for Export Credit and Investment Insurance (Russia)

EXIMBANK of Russia (Russia)

Eximbanka Slovensko (Slovakia)

Global Financial Crisis

Korporacja Ubezpieczen Kredytów Eksportowych (Poland)

Minimum Premium Rate

Organization for Economic Cooperation and Development

Oesterreichische Kontrollbank (Austria)

Servizi assicurativi e finanziari per le imprese (Italy)

Svensk Exportkredit (Sweden)

Swiss Export Risk Insurance (Switzerland)

Società italiana per le imprese all'estero (Italy)

Through the Cycle Market Benchmark model

UK Export Finance (Great Britain)

Price of financing

Prize of money

Credit risk

Market risk

Operational risk

Profit margin 


\section{References}

Augustin, P., Sokolovski, V., Subrahmanyam, M. G., et al. (2020). In Sickness and in Debt: The Covid-19 Impact on Sovereign Credit Risk. NYU Stern School of Business, https://doi.org/10.2139/ssrn.3613432

Belhoste, N., Bocquet, R., Favre-Bonté, V., et al. (2019). How Do SMEs Use Support Services During Their Internationalisation Process: A Comparative Study of French Traditional SMEs and INVs in Asia. International Small Business Journal, 37(8), 804-830, https://doi.org/10.1177/0266242619871165

Chaffour, J.-P., Saborowski, C., Soylemezoglu, A. I. (2010). Trade Finance in Crisis: Should Developing Countries Establish Export Credit Agencies? World Bank. Washington, D.C. Policy Research Working Paper No. 5166, https://doi.org/10.1596/1813-9450-5166

Dawar, K. (2020). Official Export Credit Support: Competition and Compliance Issues. Journal of World Trade, 54(3), 373-395.

De Ricolfis, F. (2011). A Long History in Facing Challenges, in Smart Rules for Fair Trade: 50 Years of Export Credits. Paris: OECD Publishing, https://doi.org/10.1787/9789264111745-22-en

European Commission (2020). Temporary Framework to Support the Economy in the Context of the Coronavirus Outbreak. Bruxelles: European Commission. Available at: https://ec.europa.eu/competition/state_aid/what_is_new/covid_19.html

Fama, E. F., French, K. R. (2004). The Capital Asset Pricing Model: Theory and Evidence. Journal of Economic Perspectives, 18(3), 25-46, https://doi.org/10.1257/0895330042162430

Felbermayr, G. J., Yalcin, E. (2013). Export Credit Guarantees and Export Performance: An Empirical Analysis for Germany. The World Economy, 36(8), 967-999, https://doi. org/10.1111/twec.12031

Gründl, H., Dong, M. (I.), Gal, J. (2017). The Evolution of Insurer Portfolio Investment Strategies for Long-term Investing. OECD Journal: Financial Market Trends, 2016(2), 1-55, https://doi.org/10.1787/fmt-2016-5jln3rh7qf46

Ilias, S., Fergusson, I. F., Morisson, W. M., et al. (2012). Boosting U.S. Exports: Selected Issues for Congress. Congressional Research Service. Available at: https://fas.org/sgp/crs/misc/ R41929.pdf

Janda, K., Michalikova, E., Skuhrovec, J. (2013). Credit Support for Export: Robust Evidence from the Czech Republic. The World Economy, 36(12), 1588-1610, https://doi. org/10.1111/twec.12061

Ključnikov, A., Popesko, B. (2017). Export and its Financing in The SME Segment. Case Study from Slovakia. Journal of Competitiveness, 9(1), 20-35, https://doi.org/10.7441/ joc.2017.01.02

Navarro-Galera, A., Rayo-Cantón, S., Lara-Rubio, J., et al. (2015). Loan Price Modelling for Local Governments Using Risk Premium Analysis. Applied Economics, 47(58), 6257-6276, https://doi.org/10.1080/00036846.2015.1068924 
OECD (2017). Guidance on Premium Rules for Officially Supported Export Credits in Market Benchmark Countries. Paris: OECD.

OECD (2020). The Red Book. Arrangement on Officially Supported Export Credit.

Paris: OECD. Available at: http://www.oecd.org/officialdocuments/

publicdisplaydocumentpdf/?doclanguage $=e n \& \operatorname{cote}=\operatorname{tad} / p g(2020) 1$

Pycha, M. (2020).Problems with Long-term Financial Sustainability of Export Credit Agencies. Prague Economic Papers, 30(2), 156-176, https://doi.org/10.18267/j.pep.762

Saghir, W. (2020). Corporate Structure and Governance of Export Credit Agencies: A UKEF Overview. Financial Law Review, 18(2), 1-12, https://doi.org/10.4467/22996834flr. 20.006.12428

Sharov, V. F., Pinskaya, M. R., Bogachev, S. V. (2018). Improving Governmental Support for the Export Credit of Foreign Trade in the Eurasian Space. Economic and Social Changes: Facts, Trends, Forecast, 11(5), 74-86, https://doi.org/10.15838/esc.2018.5.59.5

World Trade Organisation (2020). Agreement on Subsidies and Countervailing Measures. Genève:World Trade Organization. Available at: https://www.wto.org/english/docs_e/ legal_e/24-scm_01_e.htm 